\title{
The Determinants of Tax Avoidance within Corporate Groups: Evidence from Moroccan Groups
}

\author{
Dayday Anouar ${ }^{1}$, Zaam Houria ${ }^{2}$ \\ ${ }^{1}$ Faculty of Law, Economics and Social Sciences, University Abdelmalek Essaâdi, Tangier, Morocco \\ ${ }^{2}$ Faculty Polydisciplinary, University Abdelmalek Essaâdi, Tetouan, Morocco
}

Email address:

anouardayday@gmail.com (D. Anouar), zaamhr@yahoo.fr (Z. Houria)

To cite this article:

Dayday Anouar, Zaam Houria. The Determinants of Tax Avoidance within Corporate Groups: Evidence from Moroccan Groups. International Journal of Economics, Finance and Management Sciences. Vol. 5, No. 1, 2017, pp. 57-65. doi: 10.11648/j.ijefm.20170501.15

Received: December 3, 2016; Accepted: December 15, 2016; Published: January 9, 2017

\begin{abstract}
This paper examines the major tax avoidance determinants within the corporate groups, based on a hand-collected sample of 45 publicly-listed Moroccan corporate groups, over the 2011-2015 period. The literature review indicate that there are several practices of Moroccan corporate groups, used to reduce their tax liabilities, specially, we find, Group size, Intragroup transactions, Profitability, Intangible Assets, Debts, and Multinationality. Finally, our regression results show that only the multinationality, intra-group transactions and Debts are used to maximize tax avoidance opportunities, therefore to reduce the group's tax liabilities.
\end{abstract}

Keywords: Corporate Groups, Tax Avoidance, Intra-group Transactions, Intangible Assets, Debts

\section{Introduction}

Taxation was always considered as a Tax burden which blocked the development of companies. Nowadays, in a national and international competitive context, the taxation occupies an important place in the company strategic decisions, particularly in terms of location and investment, and it's also a key factor for competitiveness in a competitive environment. From now on, taxation has become the main concern of all companies. This new trend encourages companies to adopt a more active and dynamic attitude towards their tax management, and this through the tax avoidance practices which constitute for the company a real lever of success and financial performance.

The economic literature is very rich of studies on corporate taxation in general, while there is just little work on the question of tax avoidance within corporate groups specifically. Some researchers have attempted to define the concept of tax avoidance, in which Flesch's work [1], defined it as the art of avoiding tax without actually breaking the law. So Oats [2] considered this definition as broad and fails to grasp the nuances and the distinctions between the acceptable and unacceptable tax avoidance". Other authors [3] considered tax avoidance as a legal activity. The question of what is lawful remains ambiguous. Pallan [4] also confirmed this finding by considering tax avoidance as a legal activity on the legal and economic side, while too much avoidance can turn into tax evasion which is for some specialists an illegal activity. Similarly, Abudlrazaq [5] and Oats [2] have confirmed that tax avoidance is generally considered a legal practice against tax evasion. Thus, Killian and Kolitz, [6] have concluded that the tax avoidance is a legal practice because tax legislation is often open to interpretation.

The complexity of tax legislation often lies in the diversity of interpretations that sometimes contradict with the spirit of the law [8]. Indeed, studies by Sikka [3] have confirmed that the various interpretations of the tax law letter are the tax avoidance source. The work of Duff [10] also showed that some forms of tax avoidance are clearly acceptable while others remain ambiguous. Although some highly sophisticated optimization techniques designed to reduce the tax burden, and they could be considered an illegal activity. Alm [11] found that tax avoidance can take various legal and illegal forms, while it is influenced by the incentives created by the tax system.

Internationally, the multinational groups often manipulate transfer pricing policies in order to transfer their profits from high tax areas to those with little or no taxation [12]. It should also be pointed out that this transfer pricing practice is rooted in the culture of many western firms [14]. 
The question of our work consists of examining the determinants of tax avoidance within corporate groups, such as the means by which the corporate groups can use in order to reduce their tax liabilities. In the same way, our objective is to evaluate the impacts of tax avoidance determinants on the tax liabilities of the groups, while using the effective tax rate (ETR) as a tax avoidance measure.

The importance of our research work appears at several levels; In the first place, our study is the first in Morocco in which it studies the determinants of tax avoidance within the corporate groups. Secondly, this study contributes to the development of research on the taxation of corporate groups [17], [26], [19], [20], and this is through the construction of a tax avoidance measure within groups, at the end, our study provides a global view on how the Moroccan listed groups engage in tax avoidance.

Our empirical evidence study focuses on a sample of 45 corporate groups listed on the Casablanca Securities Exchange, for a period of 5 years, from 2011 to 2015. This study consists of analyzing the consolidated financial statements and the information notes relating to the financial transactions of the corporate groups. In fact, the results of this study (multiple regression method) showed that the intragroup transactions, debts and multinationality are significantly associated with the tax avoidance of corporate groups. Consequently, they represent the main determinants of tax avoidance within corporate groups.

The remainder of this paper is organized as follows: Section 2 presents a brief review of the U.S. literature on the topic of group tax avoidance; Section 3 develops our hypotheses; Section 4 discusses the research design; Section 5 summarizes and analyzes the empirical results. Finally, Section 6 concludes the paper.

\section{Theory and Hypotheses Development}

Anglo-Saxon literature is also very rich in tax matters. Several authors have addressed the issue of group taxation by examining tax management practices and their impact on group performance. To this context, Taylor and Richardson [23] examined tax management practices within corporate groups and found that transfer pricing and the use of intragroup debt are the most widely used techniques to reduce the tax liabilities on groups. Thus, in 2013, consideration is given to transfer pricing determinants as a means by which corporate groups can significantly reduce their tax liabilities [19], [20]. Also, another study has shown that the use of excessive funding between subsidiaries located in tax-deferred areas is an important tax management technique for corporate groups [20]. Moreover, a recent study conducted in the Tunisian context confirmed that groups of financial companies mainly use profit relief techniques and intra-group transactions in order to reduce their effective tax rate [24], For some authors, undercapitalization and transfer pricing are the main determinants of tax avoidance within corporate groups [23].

We develop several hypotheses concerning the determinants of tax avoidance. To this case, several variables are supported to represent the main determinants of tax avoidance within corporate groups, namely intra-group transactions, group size, debts, multinationality, profitability and intangible assets. The literature review highlighted the following findings.

\subsection{Group Size}

Generally, large corporations engage in more commercial activities and financial transactions than small ones, providing them with significant opportunities to significantly reduce corporate taxes [16]. The large corporate groups tend to operate between group subsidiaries (leasing and financing transactions). They can also take advantage of the possibilities of tax arbitrage between different tax jurisdictions.

In addition, Slemrod [26] found that the cost of tax management in large firms is lower than that of small firms. As a result, large firms can achieve economies of scale through tax planning, and also have additional resources and incentives to reduce the tax burden [16].

The research conducted by Bernard [36] found that large firms are manipulating transfer pricing. Furthermore, Hanlon [38] concluded that large firms generally exploit shortcomings in the tax law to reduce their tax liabilities.

Finally, the research of Benvignati, Al-Eryani, Conover and Nichols [30] have also found that large firms are most likely to manipulate transfer pricing in order to optimize their tax results.

To formally test the impact of group size on tax avoidance, we develop the following hypothesis:

H1. The group size is positively associated with the tax avoidance.

\subsection{Debts}

Highly indebted firms are likely to take advantage of the main characteristics of debt-capital (the fungibility of borrowed funds) in order to avoid a significant corporate tax burden [31], [32], [33]. Thus, [34] Multinational groups prefer to finance their subsidiaries with debt or equity transfers, these transfers are motivated by the possibilities of tax arbitrage between the zones for purely tax purposes.

In fact, tax considerations have made debt financing, the preferential form of financing in areas with high taxation [31], [16], [33].

Moreover, studies have confirmed that companies with a higher debt ratio are the companies that pay less tax. Indeed, Walsh and Ryan [35] find that firms frequently issue debt from foreign finance subsidiaries, particularly in favorable tax jurisdictions such as the Netherlands, to avoid paying interest withholding tax and to achieve tax deductibility of interest payments. Arbitrage activities of this kind demonstrate the connection between a firm's strategies and its financing and tax decisions.

In addition, a study by Rego [16] finds that firms with very high leverage also have a very low effective tax rate, as these firms use interest deductions to The amount of tax payable and also include very low tax provisions in the financial accounts. Previous research by Bernard [36] showed that 
firms with high debt-to-equity ratios tend to pay less tax than firms with low debt-to-equity ratios.

In fact, a multinational group is encouraged to finance its foreign direct investment with debt if the corporate tax rate of the host country is higher than that of the corporate tax rate of the country of origin. In these cases, the company will be able to deduct interest payments at a higher rate if the loan is made by a foreign subsidiary rather than by the parent company [37]. In the American context, the study by Dyreng, [33] found that the success of long-term tax avoidance is significantly associated with higher leverage for US firms.

Finally, the latest studies by Taylor and Richardson [23] have confirmed that the financing operations (indebtedness) of the corporate group is strongly associated with the effective tax rate, the more the group is indebted, the more its ability to reduce the tax liabilities.

To formally test the impact of debts on tax avoidance, we develop the following hypothesis:

H2. Debts are positively associated with tax avoidance.

\subsection{Intra-group Transactions}

The work of Desai [14] showed that the transactions between subsidiaries located in areas with different taxation and offer more opportunities for tax avoidance. Moreover, Chadefaux and Rossignol have also confirmed that multinational groups can use intra-group transactions in order to optimize their tax management, by adopting an artificial transfer pricing strategy. They also added that the management of transfer prices between the subsidiaries of the same group constitutes a reel leverage of tax avoidance.

In 2000, Johnson studied the issue of transferring the profits from minority shareholders to the controlling shareholders (parent company) in the countries of Western Europe. Moreover, he demonstrated that this operation passes through intra-group transactions. From another point of view, most of the studies which done on the groups taxation have focused on intra-group transactions such as: the transactions between group subsidiaries and related companies, while they are trying to analyze the existence of tunnels and its size [57], [58], [59].

In addition, an in-depth examination of Korean companies concerning the profit transfer through intra-group transactions indicates that tunneling is not uniformly produced in all subsidiaries of business groups, because the intra-group transactions have both a negative and a positive aspect [60].

To formally test the impact of Intra-group transactions on tax avoidance, we develop the following hypothesis:

H3. Intra-group transactions are positively associated with tax avoidance.

\subsection{Intangible Assets}

Intangible assets (intellectual property, goodwill, patents and $\mathrm{R} \& \mathrm{D}$ expenditure) are the subject of several studies, they are the key issue in the tax avoidance process within corporate groups, which is about transferring of intangible assets between Group entities [47], [48]. The studies by
Gravelle [49] found that Intangible assets and the transfer of payments (ie royalties allocated to intangible assets) are difficult to evaluate..

In fact, Grubert [47], showed that the transfer risk of intangible assets increases by the variability of interpretation of transfer pricing evaluations and the difficulty for firms to define precisely the transaction in which the transfers of ownership Intangibles take place.

Finally, the intangible assets are characterized by the absence of a well-established market and subjective valuation that can be exploited in different jurisdictions. As a result, there is a big possibility of tax avoidance on the intangible assets' transfer when there is a difference in the effective tax rate between different jurisdictions [50].

To formallytest the impact of Intangible assets on tax avoidance, we develop the following hypothesis:

H4. Intangible assets arepositively associated with tax avoidance.

\subsection{Profitability}

The corporate profitability is the main determinant of its performance, Rego's [16] research has shown that firms with high profitability are most likely to engage in tax avoidance practices in order to reduce their tax liabilities. In addition, the study by Wilkie [41] and Limberg [42] found a positive relationship between pre-tax and effective tax rates. Rego [16] also reported that firms with higher pre-tax incomes are more likely to reduce taxes than firms with less pre-tax income. In other words, the most profitable firms can aggressively use transfer pricing techniques to transfer profits from high-tax areas to low-tax areas. The most famous example of this type of practice is that of companies such as: Apple, Google and Microsoft. they are the most profitable structures and they preferentially locate their profits in low tax jurisdictions and increase deductible expenses (royalties) in high tax jurisdictions, in order to reduce taxable profits [43], [45], [46].

To formally test the impact of profitability on tax avoidance, we develop the following hypothesis:

H5. Profitability is positively associated with tax avoidance.

\subsection{Multinationality}

Multinational companies are always seeking to optimize their tax management through effective tax planning strategies of all Group subsidiaries [16], [38]. The corporate that having foreign source profit from subsidiaries, will have more opportunities to engage in tax avoidance. Indeed, multinational companies have more possibilities to reduce their tax liabilities through the location of their activities in areas with low or no taxation. This operation is done by transferring the profits from high tax jurisdictions to low tax jurisdictions while exploiting the differential in the tax rate between countries [26]. In fact, Slemrod also confirmed that multinational groups use a set of optimization and tax planning techniques to significantly reduce the group's effective tax burden. Rego [16] also observed that multinational companies have more opportunity 
to avoid corporation tax than domestic firms. Moreover, the multinationals can also achieve economies of scale in their management and tax planning by using the intra-group transactions.

In addition, Mills and Newberry [39] found that multinational corporations report lower taxable earnings in US subsidiaries than foreign subsidiaries located in areas with a relatively lower tax rate. Hanlon [38] observed that firms under foreign control are more motivated to increase their degree of tax avoidance than domestic controlled firms. Similarly, the study by Dyreng [33] showed that firms with high international exposure have more opportunities for tax avoidance. Moreover, Benvignati [28] also demonstrated in his study that the corporate groups with a large number of foreign subsidiaries are more involved in transfer pricing and tax avoidance strategies. Finally, Jacob [40] indicated that the multinational corporations have more opportunity to manipulate transfer pricing in order to reduce their tax liabilities due to the tax rate differential between the United States and group entities located abroad.

To formally test the impact of Multinationality on tax avoidance, we develop the following hypothesis:

H5. Multinationality is positively associated with tax avoidance.

\section{Research Design}

\subsection{Sample Selection and Data Source}

Our sample was initially composed of 50 corporate groups listed on the Moroccan stock exchange fora five-year period from 2011 to 2015. The sample then was reduced to 45 groups after excluding certain groups for the lack of financial information, Total of 225 observations. We choose these five exercises because they represent the latest data published by the listed Moroccan groups. Finally, all financial data used were collected manually from the consolidated financial statements and the annual reports published by the Moroccan Capital Market Authority (AMMC).

\subsection{Base Regression Model}

We use the multiple regression model whose parameters will be estimated by the Ordinary Least Squares (OLS) method. The regression model is estimated as follows:

Tax liabilities (ETR) $(\mathrm{Y})=\mathrm{C}+$ Group size $(\mathrm{X} 1)+$ debts $(\mathrm{X} 2)+$ intra-group transactions $(\mathrm{X} 3)+$ intangible assets $(\mathrm{X} 4)$ + Profitability $(\mathrm{X} 5)+$ multinationality $(\mathrm{X} 6)+\ell$ (residual)

\subsection{Dependent Variable}

The variable (Y) represents the tax liabilities of the group and consequently the degree of tax avoidance, since the economic literature has shown that the degree of tax avoidance has often been measured by the effective tax rate [52], [33]. In this case, we also use the effective tax rates (ETR) as a dependent variable, determined by the ratio of the sum of cash tax paid over the 2011-2015 period divided by the sum of pre-tax accounting income over that same period.

In addition, tax avoidance has been defined by Schmidt, as the set of legal techniques that minimize the corporate tax burden. In other words, it uses all tax advantages offered by the tax system, to minimize the group tax liabilities

\subsection{Independent Variables}

Our independent variables are denoted by the group size (X1), debt (X2), intra-group transactions (X3), intangible assets (X4), profitability (X5) and Multinationality (X6).

The group size is measured by the turnover. Moreover, Profitability is measured by the pre-tax result according to the research of Rego [16]. The group debt is measured by the group's debt level in accordance with the work of Stickney and McGee in 1982 and Gupta and Newberry [32]. The intangible assets are also measured by the level of intangible assets of the group. The multinationality is measured by the existence of subsidiaries abroad. Finally, intra-group transactions are also measured by the level Of transactions between subsidiaries.

\section{The Empirical Results}

\subsection{Descriptive Statistics}

The table 1 below summarizes the descriptive statistics of the dependent variable $(\mathrm{Y})$ and the independent variables $(\mathrm{X} 1$, $\mathrm{X} 2, \mathrm{X} 3, \mathrm{X} 4, \mathrm{X} 5, \mathrm{X} 6$ ) for the period 2011-2015

Table 1. Descriptive Statistics of Different Variables.

\begin{tabular}{|c|c|c|c|c|c|c|c|}
\hline & $\mathbf{Y}$ & $\mathbf{X 1}$ & $\mathbf{X} 2$ & $\mathbf{X 3}$ & $\mathrm{X} 4$ & $\mathrm{X5}$ & X6 \\
\hline Mean & 0.302833 & 6651524. & 4955126. & 820571.6 & 1847264. & 1240632. & 0.444444 \\
\hline Median & 0.304640 & 3001024. & 1133389. & 254600.0 & 49694.00 & 351694.0 & 0.000000 \\
\hline Maximum & 0.486288 & 59383000 & 53613257 & 14526378 & 55000000 & 19430000 & 1.000000 \\
\hline Minimum & 0.156684 & 83529.00 & 0.000000 & 7645.000 & 0.000000 & 4600.000 & 0.000000 \\
\hline Std. Dev. & 0.180972 & 12137972 & 9607266. & 1812618. & 6975030. & 2862397. & 0.498012 \\
\hline Skewness & -0.140419 & 2.894777 & 2.771858 & 4.584991 & 5.274834 & 3.810747 & 0.223607 \\
\hline Kurtosis & 2.980148 & 10.43486 & 10.28350 & 28.01434 & 32.23629 & 18.58434 & 1.050000 \\
\hline Sum & 68.13744 & $1.50 \mathrm{E}+09$ & $1.11 \mathrm{E}+09$ & $1.85 \mathrm{E}+08$ & $4.16 \mathrm{E}+08$ & $2.79 \mathrm{E}+08$ & 100.0000 \\
\hline Observation & 225 & 225 & 225 & 225 & 225 & 225 & 225 \\
\hline
\end{tabular}

Source: (EViews) financial reports of the corporate groups

***: Statistically significant at risk levels $1 \%, 5 \%$ et $10 \%$

Effective tax rates (ETR) (Y), Group size (X1), Debts (X2), Intra-group transactions (X3), intangible assets (X4), Profitability (X5), Multinationality (X6) 
According to Table 1, it can be seen from the 225 observations that the effective tax rates averaged $30.2833 \%$, minimum $15.668 \%$ and maximum $48.6288 \%$

\subsection{Correlation Matrix}

The correlation matrix between the different variables is as follows:

Table 2. Correlation matrix.

\begin{tabular}{|c|c|c|c|c|c|c|c|}
\hline & $\mathbf{Y}$ & X1 & $\mathrm{X} 2$ & $\mathbf{X 3}$ & X4 & X5 & X6 \\
\hline $\mathrm{Y}$ & 1.000000 & 0.661577 & 0.478010 & 0.257216 & 0.050971 & 0.929720 & 0.297967 \\
\hline $\mathrm{X} 1$ & 0.661577 & 1.000000 & 0.485202 & 0.586670 & 0.345693 & 0.712391 & 0.052400 \\
\hline $\mathrm{X} 2$ & 0.478010 & 0.485202 & 1.000000 & 0.325978 & 0.462015 & 0.443199 & 0.085171 \\
\hline $\mathrm{X} 3$ & 0.257216 & 0.586670 & 0.325978 & 1.000000 & 0.359468 & 0.282666 & 0.057821 \\
\hline $\mathrm{X} 4$ & 0.050971 & 0.345693 & 0.462015 & 0.359468 & 1.000000 & 0.045853 & -0.186220 \\
\hline X5 & 0.929720 & 0.712391 & 0.443199 & 0.282666 & 0.045853 & 1.000000 & 0.287601 \\
\hline X6 & 0.297967 & 0.052400 & 0.085171 & 0.057821 & -0.186220 & 0.287601 & 1.000000 \\
\hline
\end{tabular}

Source: EViews output computed from financial reports of the corporate groups

The correlation matrix shows the existence of three categories of variables:

(1) The strong correlation Variables with the dependent variable are:

- X1: Group size

- X5: Profitability

The X5 variable coefficient shows a problem of multicollinearity, so it will be removed from the model.

(2) The medium correlation Variables with the dependent variable are:

$-\mathrm{X} 2$ : Debts

-X4: Intangible assets

(3) The low correlation Variables with the dependent variable are:

- X3: Intra-group transactions

- X6: Multi-nationality

\subsection{Regression Results}

Using the Eviews software, and having eliminated the X5 variable, the Table 3 below presents the multiple regression results of our LSM model using the Least Squares method:

Table 3. Result of estimation of the LSM model.

\begin{tabular}{|c|c|c|c|}
\hline \multicolumn{4}{|c|}{ Dependent Variable: Y } \\
\hline \multicolumn{4}{|c|}{ Method: Least Squares } \\
\hline \multicolumn{4}{|c|}{ Date: 10/02/16 Time: 02:19 } \\
\hline \multicolumn{2}{|c|}{ Sample: 1225} & R-squared & 0.992360 \\
\hline \multicolumn{2}{|c|}{ Included observations: 225} & Prob (Fstatistic) & 0.000189 \\
\hline Variable & Coefficient & t-Statistic & Prob. \\
\hline $\mathrm{C}$ & 0.301973 & 14.17391 & 0.0000 \\
\hline $\mathrm{X} 1$ & 3.233409 & -1.455850 & 0.3469 \\
\hline $\mathrm{X} 2$ & -1.372309 & 0.709659 & 0.0287 \\
\hline $\mathrm{X} 3$ & -2.571908 & 2.489761 & 0.0135 \\
\hline $\mathrm{X} 4$ & -0.792810 & -0.337516 & 0.0361 \\
\hline X6 & -0.291452 & 0.933440 & 0.0251 \\
\hline
\end{tabular}

Source: EViews

$$
\begin{gathered}
\text { TIE }(\mathrm{Y})=0.301973+3.233409(\mathrm{X} 1)-1.372309(\mathrm{X} 2)- \\
2.571908(\mathrm{X} 3)-0.792810(\mathrm{X} 4)-0.291452(\mathrm{X} 6)+\ell \mathrm{t}
\end{gathered}
$$

According to Table 3 above, the model is globally significant because the p-value of Fisher is $<5 \%$ and the square $\mathrm{R}$ of the model is in the order of $99.23 \%$, which means that the quality of Model fit is very good and the model has significant explanatory power. Whereas there is a second non-significant variable that represents the group size (X1), so it should be eliminated from the database for reestimating function.

\subsection{Correction and Analysis of Results}

After removing the non-significant variables, we will reestimate the model in order to find the optimal model using the STEPWISE regression method.

\begin{tabular}{|c|c|c|c|}
\hline \multicolumn{2}{|c|}{ Dependent Variable: Y } & R-squared & 0.995635 \\
\hline \multicolumn{4}{|c|}{ Method: Stepwise Regression } \\
\hline \multicolumn{4}{|c|}{ Date: 10/14/16 Time: 00:03 } \\
\hline \multicolumn{4}{|c|}{ Selection method: Stepwise forwards } \\
\hline \multicolumn{4}{|c|}{ Stopping criterion: $p$-value forwards/backwards $=0.05 / 0.05$} \\
\hline Variable & Coefficient & t-Statistic & Prob. \\
\hline $\mathrm{C}$ & 0.652062 & 27.69084 & 0.0000 \\
\hline $\mathrm{X} 2$ & -1.267802 & 1.210329 & 0.0475 \\
\hline $\mathrm{X} 3$ & -1.809876 & -1.828375 & 0.0389 \\
\hline $\mathrm{X} 4$ & -0.775410 & 0.505160 & 0.0840 \\
\hline X6 & -0.532580 & 0.561961 & 0.0087 \\
\hline
\end{tabular}

Table 4. Stepwise Regression Result.

Source: EViews

By applying Stepwise's regression method, it appears that a third non-significant variable has appeared, it is the variable $\mathrm{X} 4$ relating to Intangible assets, According to having eliminated it, here is the new model:

\begin{tabular}{|c|c|c|c|}
\hline \multicolumn{2}{|c|}{ Dependent Variable: Y } & R-squared & 0.995635 \\
\hline \multicolumn{4}{|c|}{ Method: Stepwise Regression } \\
\hline \multicolumn{4}{|c|}{ Date: $10 / 14 / 16$ Time: 00:13 } \\
\hline \multicolumn{4}{|c|}{ Selection method: Stepwise forwards } \\
\hline Variable & Coefficient & t-Statistic & Prob. \\
\hline $\mathrm{C}$ & 0.652062 & 27.69084 & 0.0000 \\
\hline $\mathrm{X} 2$ & -1.267802 & 1.210329 & 0.0475 \\
\hline $\mathrm{X} 3$ & -1.809876 & -1.828375 & 0.0389 \\
\hline X6 & -0.532580 & 0.723560 & 0.0087 \\
\hline
\end{tabular}

Table 5. Stepwise final result.

Source: EViews 


$$
\begin{gathered}
\operatorname{ETR}(\mathrm{Y})=0.652062-1.267802(\mathrm{X} 2)-1.809876(\mathrm{X} 3)- \\
0.532580(\mathrm{X} 6)+\ell \mathrm{t}
\end{gathered}
$$

The following conclusions can be drawn from the analysis of the results above:

(1) The increase in the level of indebtedness by $1 \%$ leads to a decrease in the EIR of $1.267802 \%$.

(2) The increase in intra-group transactions by $1 \%$ leads to a decrease in the EIR of $1.809876 \%$.

(3) The creation of a subsidiary abroad (the multinationality) leads to a reduction of the EIR of $0.532580 \%$.

(4) The other variables remained constant.

Firstly, our regression results also showed that intra-group transactions are negatively associated with the effective tax rate, while the corporate groups carry out many internal transactions in order to transfer the profits from the beneficiary subsidiaries to the deficit subsidiaries and that for reducing the tax liability.

Secondly, the level of indebtedness is negatively associated with the effective tax rate. The Moroccan corporate Groups use debt financing between subsidiaries. This form of financing generates interest expenses that can be deducted from their tax income. For that, most firms prefer to choose debt financing than to use their own means,

Finally, the multinationality is positively associated with the effective tax rate. The corporate groups have many opportunities to reduce corporate taxes by locating operations in low-tax jurisdictions, by shifting income from high-tax jurisdictions to low-tax jurisdictions, and by exploiting variations in the tax rules of different countries

\subsection{Residual Diagnostic Test}

(1) test normality of residuals

We are going to verify the normality of residues, and one of those hypotheses below should be checked:

$\mathrm{H} 0$ : residuals are normally distributed.

H1: Residuals are not normally distributed.

The following table shows the residual histogram of our model

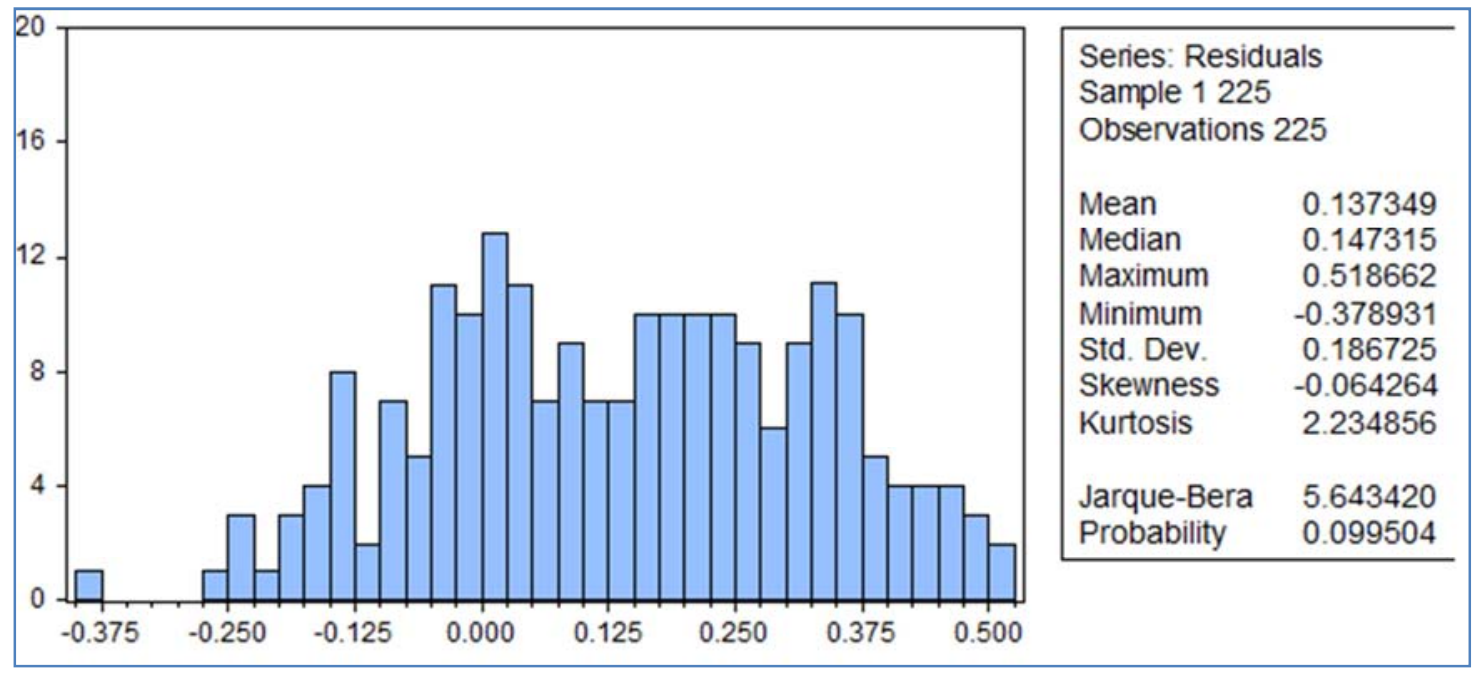

Figure 1. The residuals histogram.

According to table 6 above, the probability of the JarqueBera statistic, provided by Eviews, is morethan 5\% (0.099504> 0.05), therefore, the hypothesis Ho of Residuals normality is accepted. So, it should be concluded that residues are normally distributed.

(2) Heteroskedasticity test of residuals

To verify the residual heteroscidasticity, the following two hypotheses must be verified:

Ho $=$ Residuals are homoscedastic

$\mathrm{H} 1=$ Residuals are heteroskedastic

\begin{tabular}{|c|c|c|c|}
\hline \multicolumn{4}{|c|}{ Heteroskedasticity Test: Breusch-Pagan-Godfrey } \\
\hline \multicolumn{4}{|c|}{ Dependent Variable: RESID $^{\wedge} \mathbf{2}$} \\
\hline \multicolumn{4}{|c|}{ Method: Least Squares } \\
\hline F-statistic & 1.427983 & Prob. F $(4,172)$ & 0.08451 \\
\hline Obs*R-squared & 8.508607 & Prob. Chi-Square (6) & 0.0032 \\
\hline
\end{tabular}

Table 6. Heteroskedasticity test of residuals.

Source: EViews
After the Breusch-Pagan-Godfrey test, we found that the Ho hypothesis is verified because the probability of $\mathrm{F}$ statistic is more than $5 \%(0.05)$. Therefore, it should be confirmed that the residues are homoscidasticitic.

(3) Autocorrelation test

To check the non-auto correlation of residuals, it is necessary to verify the following two hypotheses:

- H0: residues are non-auto-correlated

- H1: residues are self-correlated

Table 7. Autocorrelation test of residuals.

\begin{tabular}{l}
\hline \multicolumn{4}{l}{ Breusch-Godfrey Serial Correlation LM Test: } \\
\begin{tabular}{llll}
\hline Dependent Variable: RESID \\
\hline \multicolumn{4}{l}{ Method: Least Squares } \\
\hline F-statistic & 2.379830 & Prob. F (6,218) & 0.0876 \\
Obs*R-squared & 4.851083 & Prob. Chi-Square (6) & 0.0484 \\
\hline
\end{tabular}
\end{tabular}

Source: EViews 
Following the results of the Breusch-Godfrey test above, the probability of $\mathrm{F}$ statistic is more than $5 \%(0.0876)$. The hypothesis $\mathrm{HO}$ is verified, therefore the residuals are not selfcorrelated.

By performing the residuals analysis, the model is clearly identified after the validity of all the tests, specially, the homoscedasticity test, the independence test and the normality test. Finally, the results of this study confirmed the advanced theoretical analysis.

\section{Conclusion}

This study examines the main determinants of tax avoidance within Morroccan corporate groups listed on the Casablanca Stock Exchange. The regression results confirmed the validity of the hypotheses put forward $(\mathrm{H} 2, \mathrm{H} 3$, and H6) during our work, which means that intra-group transactions, group indebtedness, multinationality are negatively associated with The Group's tax burden. it should be concluded that these three variables represent the main determinants of tax avoidance within the corporate groups. Therefore, they contribute significantly to reduce the tax liabilities. However, our study is including several limitations. First of all, the data used in our study are derived from the financial statements published by corporate groups listed on the stock exchange, whereas the unlisted corporate groups are excluded from our sample. Secondly, the absence of a tax consolidation regime in Morocco does not make it possible to correctly assess the impact of these determinants on the effective tax rate of the group.

Finally, our basic regression model could not be perfect, whereas, the tax avoidance determinants tested in our model represent only certain internal variables of the group, but there are other variables that have not been Taking into consideration and influencing the tax avoidance process such as: the relationship of the directors' board with the shareholders, the role of the tax authority, the personnel's skills and the tax havens. However, these variables were excluded due to the lack of data. Future research can examine this issue.

\section{References}

[1] Flesch MC. Tax avoidance: the attitude of the courts and the legislature. Current Legal Problems 1968; 21: 215-38.

[2] Oats L. Distinguishing closely held companies for taxation purposes: the Australian experience 1930-1972. Accounting, Business and Financial History 2005; 15 (1): 335-61.

[3] Sikka, P., \& Haslam, C. (2007). Transfer pricing and its role in tax avoidance and flight of capital: some theory and evidence. In Centre for global accountability, seminar seriesUniversity of Essex, UK.

[4] Pallan R, Murphy R, Chavagneux C. Tax havens: how globalisation really works. London: Cornell University Press; 2010 .

[5] Abudlrazaq MT. The legal nature of tax evasion and avoidance. Nigerian Financial Review 1992; 4 (3): 65-74.

[6] Killian S, Kolitz M. Revenue approach to income tax evasion: a comparative study of Ireland and South Africa. Journal of Accounting, Ethics and Public Policy 2004; 4 (4): 235-57.

[7] Hanno DM, Violette GR. An analysis of moral and social influences on taxpayer. Behavioural Research in Accounting 1996; 8: 57-75.

[8] Bond S, Bae, K. H., Kang, J. K., \& Kim, J. M. (2002). Tunneling or value added? Evidence from mergers by Korean business groups. The journal of finance, 57 (6), 2695-2740.

[9] Sikka P. Smoke and mirrors: corporate social responsibility and tax avoidance. In: Centre for global accountability, seminar series. UK: University of Essex; 2010.

[10] Duff DG. Tax avoidance in the 21st Century. In: Evans C, Krever R, editors. Australian business tax reform in retrospect and prospect. Thomson; 2009.

[11] Alm J, Bahl R, Murray MN. Tax structure and tax compliance. The Review of Economics and Statistics 1990; 72 (4): 603-13.

[12] H., \& Mutti, J. (1991). Taxes, tariffs and transfer pricing in multinational corporate decision making. The Review of Economics and Statistics, 73, 285-293.

[13] Usmen, N., 2012. Transfer prices: a financial perspective. Journal of International Financial Management and Accounting 23 (1), 1-22.

[14] Desai, M. A., Foley, C. F., Hines, J. R., 2006. Do tax havens divert economic activity? Economics Letters 90, 219-224.

[15] Braithwaite, J. (2005). Markets in vice, markets in virtue. Sydney: Federation Press.

[16] Rego, S. O. (2003). Tax-avoidance activities of U.S. multinational firms. Contemporary Accounting Research, 20 (4), 805-833.

[17] Slemrod, J., \& Wilson, J. D. (2009). Tax competition with parasitic tax havens. Journal of Public Economics, 93, 12611270.

[18] Taylor, G., \& Richardson, G. (2014). Incentives for corporate tax planning and reporting: Empirical evidence from Australia. Journal of Contemporary Accounting \& Economics, 10 (1), 115.

[19] Richardson, G., Taylor, G., Lanis, R., 2013. The impact of board of director oversight characteristics on corporate tax aggressiveness: an empirical analysis. Journal of Accounting and Public Policy 32 (3), 68-88.

[20] Richardson, G., Taylor, G., \&Lanis, R. (2013). Determinants of transfer pricing aggressiveness: Empirical evidence from Australian firms. Journal of Contemporary Accounting \& Economics, 9 (2), 136-150.

[21] Chen, H., \& Frank, M. Z. (2016). The Effect of Taxation on Corporate Financing and Investment.

[22] Dyreng, S. D., Hanlon, M., \&Maydew, E. L. (2010). The effects of executives on corporate tax avoidance. The Accounting Review, 85 (4), 1163-1189.

[23] Taylor, G., Richardson, G., 2012. International corporate tax avoidance practices: evidence from Australian firms. Int. J. Account. 47, 469-496. 
[24] Menchaoui, I., \&Omri, M. A. (2012). Determinants of practice of corporate tax in Tunisian context. International Journal of Managerial and Financial Accounting, 4 (4), 325-338.

[25] Menchaoui, I. (2015). Identification et impact des pratiques de gestion fiscale sur la performance fiscale des groupes de sociétés: une étude menée dans le contexte tunisien (Doctoral dissertation, Université de Franche-Comté).

[26] Slemrod, J. (2001). A general model of the behavior response to taxation. International Tax and Public Finance, 8 (2), 119 128

[27] Auerbach, A. J., Hines Jr, J. R., \&Slemrod, J. (Eds.). (2007). Taxing corporate income in the 21st century. Cambridge University Press.

[28] Benvignati, A. M., 1985. An empirical investigation of international transfer pricing by U.S. manufacturing firms. In: Rugman, A. M., Eden, L. (Eds.),

[29] Al-Eryani, M. F., Alam, P., Akhter, S. H., 1990. Transfer pricing determinants of U.S. multinationals. Journal of International Business Studies 21 (3), 409-425.

[30] Conover, T. L., Nichols, N. B., 2000. A further examination of income shifting through transfer pricing considering firm size and/or distress. The International Journal of Accounting 35, 189-211.

[31] Hines, J. R., 1996. Tax policy and the activities of multinational corporations. NBER Working Paper.

[32] Newberry, K. Y., Dhaliwal, D. S., 2001. Cross-jurisdictional income shifting by U.S. multinationals: evidence from international bond offerings. Journal of Accounting Research 39 (3), 643-662.

[33] Dyreng, S., Hanlon, M., Maydew, E., 2008. Long-run corporate tax avoidance. The Accounting Review 83 (1), 6182.

[34] Richardson, G., Hanlon, D., Nethercott, L., 1998. Thin capitalization: an Anglo-American comparison. The International Tax Journal 24 (2), 36-66.

[35] Walsh, E. J., Ryan, J., 1997. Agency and tax explanations of security issuance decisions. J. Bus. Finan. Account. 24 (7/8), 943961.

[36] Bernard, A. B., Jensen, J. B., Schott, P. K., 2006. Transfer Pricing by U.S.-Based Multinational Firms. NBER Working Paper 12493.

[37] Dahlby, B. G. (2008). Taxation of inbound direct investment: Economic principles and tax policy considerations. Advisory Panel on Canada's System of International Taxation.

[38] Hanlon, M., Mills, L., \& Slemrod, J. (2007). An empirical examination of corporate tax noncompliance. In A. Auerbach,

[39] Mills, L. F., \& Newberry, K. J. (2004). Do foreign multinationals' tax incentives influence their U.S. incomereporting and debt policy? National Tax Journal, 57 (1), 89-107.

[40] Jacob, J., 1996. Taxes and transfer pricing: income shifting and the volume of intrafirm transfers. Journal of Accounting Research 34 (2), 301-313.

[41] Wilkie, P., 1988. Corporate average effective tax rates and inferences about relative tax preferences. Journal of the American Taxation Association 10 (2), 75- 88.

[42] Wilkie, P., Limberg, S., 1993. Measuring explicit tax (dis)advantage for corporate taxpayers: an alternative to average effective tax rates. Journal of the American Taxation Association 15 (1), 46-71.

[43] Mutti, J., Grubert, H., 2009. The effect of taxes on royalties and the migration of intangible assets abroad. In: Reinsdorf, M., Matthew, J. (Eds.), International

[44] Nerudova, D. (2015). group taxation under the system of common consolidated corporate tax base. economics and management, (14), 871-877.

[45] Womack, B., Drucker, J., 2011. Google questioned by SEC over earnings in low-tax countries. Bloomberg News, March 21 st.

[46] Duhigg, C., Kocieniewski, D., 2012. How Apple sidesteps billions in taxes. The New York Times, April 29th.

[47] Grubert, H., 2003. Intangible income, intercompany transactions, income shifting and the choice of location. National Tax Journal 56 (1, Part 2), 221-242.

[48] Grubert, H., Mutti, J., 2007. The effect of taxes on royalties and the migration of intangible assets abroad. NBER Working Paper 13248.

[49] Gravelle, J. G., 2010. Tax Havens: International Tax Avoidance and Evasion. CRS Report for Congress. CRS, Washington, DC.

[50] Shackelford, D. A., Slemrod, J., Sallee, J. M., 2007. A unifying model of how the tax system and generally accepted accounting principles affect corporate behavior. Working Paper, University of North Carolina and University of Michigan.

[51] Desai, M., and D. Dharmapala. 2008. Corporate tax avoidance and firm value. The Review of Economics and Statistics.

[52] Desai, M., and D. Dharmapala 2006. Corporate tax avoidance and high-powered incentives. Journal of Financial Economics 79 __ : 145-179.

[53] Gordon RH, Nielsen SB. Tax evasion in an open economy: value added vs. income taxation. Journal of Public Economics 1997; 66 (2): 173-97.

[54] Contractor, F. J. (2016). Tax Avoidance by Multinational Companies: Methods, Policies, and Ethics. AIB Insights, 16 (2), 10 .

[55] McClure, R., Lanis, R., \& Govendir, B. (2016). Analysis of Tax Avoidance Strategies of Top Foreign Multinationals Operating in Australia: An Expose.

[56] Johnson, S., Boone, P., Breach, A., \& Friedman, E. (2000). Corporate governance in the Asian financial crisis. Journal of financial Economics, 58 (1), 141-186.

[57] Gordon Elizabeth, A., Henry, E., \& Palia, D. (2004). Related party transactions: Associa-tions with corporate governance and firm value. Working Paper

[58] Riyanto, Y. E., \&Toolsema, L. A. (2008). Tunneling and propping: A justification for pyramidal ownership. Journal of Banking \& Finance, 32 (10), 2178-2187. 
[59] Friedman, E., Johnson, S., \&Mitton, T. (2003). Propping and tunneling. Journal of Comparative Economics, 31 (4), 732750 .

[60] Kang, H. C., Park, K. S., \& Jang, H. (2006). Determinants of internal transactions among the member firms of Korean conglomerates. The Korean Journal of Finance, 19 (1), 77118.
[61] Klassen, K. J., Lisowsky, P., \& Mescall, D. (2016). Transfer pricing: Strategies, practices, and tax minimization. Contemporary Accounting Research.

[62] Grubert, H., \& Altshuler, R. (2016). Shifting the Burden of Taxation from the Corporate to the Personal Level and Getting the Corporate Tax Rate Down to 15 Percent. 